\title{
Degradation of Tryptophan by UV Irradiation: Influencing Parameters and Mechanisms
}

\author{
Kejia Zhang, Weicheng Fei $\mathbb{D}^{\text {, Jingxuan Ji and Yulong Yang * }}$ \\ College of Civil Engineering and Architecture, Zhejiang University, Hangzhou 310058, China; \\ zhangkj@zju.edu.cn (K.Z.); 21812066@zju.edu.cn (W.F.); 21912138@zju.edu.cn (J.J.) \\ * Correspondence: yulongy@zju.edu.cn
}

Citation: Zhang, K.; Fei, W.; Ji, J.; Yang, Y. Degradation of Tryptophan by UV Irradiation: Influencing Parameters and Mechanisms. Water 2021, 13, 2368. https://doi.org/ $10.3390 /$ w13172368

Academic Editor: Sergi Garcia-Segura

Received: 22 July 2021

Accepted: 23 August 2021

Published: 28 August 2021

Publisher's Note: MDPI stays neutral with regard to jurisdictional claims in published maps and institutional affiliations.

Copyright: (c) 2021 by the authors. Licensee MDPI, Basel, Switzerland. This article is an open access article distributed under the terms and conditions of the Creative Commons Attribution (CC BY) license (https:// creativecommons.org/licenses/by/ $4.0 /)$.

\begin{abstract}
The chlorination of dissolved amino acids can generate disinfection by-products (DBPs). To prevent the formation of DBPs, we examined the UV-induced degradation of tryptophan (Trp). In order to further understand the impact of UV disinfection on Trp, the effects of initial concentrations of $\operatorname{Trp}, \mathrm{pH}$, temperature, concentrations of $\mathrm{NO}_{3}{ }^{-}, \mathrm{HCO}_{3}{ }^{-}$and $\mathrm{Cl}^{-}$on $\operatorname{Trp}$ removal were investigated, and a degradation mechanism was also proposed. The results demonstrated that degradation fitted a pseudo first-order reaction kinetic model. The degradation of Trp was mainly caused by direct UV degradation. The apparent rate constant $\mathrm{k}_{\mathrm{obs}}$ decreased with the increase in initial Trp concentration and increased with increases in $\mathrm{pH}$ and temperature. The thermal degradation activation energy was $19.65 \mathrm{~kJ} / \mathrm{mol}$. Anions in water also had a significant influence on the degradation of Trp. $\mathrm{HCO}_{3}{ }^{-}$and $\mathrm{NO}_{3}{ }^{-}$contributed to the $\mathrm{k}_{\mathrm{obs}}$ of $\operatorname{Trp}$, but $\mathrm{Cl}^{-}$inhibited the degradation rate. By electron paramagnetic resonance (EPR) spectroscopy, $\cdot \mathrm{OH}$ was proven to be formed during the degradation of Trp by UV. Based on the intermediate products of $\mathrm{C}_{11} \mathrm{H}_{15} \mathrm{NO}_{3}, \mathrm{C}_{10} \mathrm{H}_{15} \mathrm{~N}$ and $\mathrm{C}_{9} \mathrm{H}_{13} \mathrm{~N}$ detected by LC-MS-MS, the degradation pathway of $\operatorname{Tr} p$ was speculated.
\end{abstract}

Keywords: tryptophan; UV photolysis; pseudo first-order kinetics; $\cdot \mathrm{OH}$; degradation

\section{Introduction}

Dissolved organic nitrogen in surface water bodies primarily consists of amino acids (AAs), which are present in concentrations ranging from 20 to 10,000 $\mu \mathrm{g} / \mathrm{L}$ [1]. Cai, et al. [2] detected that the total AA content in East Taihu Lake was 32,158 ng/L during autumn and approximately $3000 \mathrm{ng} / \mathrm{L}$ for the rest of the year. Dotson and Westerhoff [3] reported that the total concentration of AAs, free and combined, was in the range of 50-1000 $\mu \mathrm{g} / \mathrm{L}$ in rivers, streams and lakes. The AA concentration in natural water bodies is drastically affected by the presence of algae; AA concentrations increased with the occurrence of algal blooms $[1,4]$.

The total AA concentration includes free AAs (0.20-0.25) and combined AAs in the form of proteins, peptides and humic-bound AAs. Although the overall free AA concentration is relatively low, a small fraction remains even after the growth of cyanobacteria or blue-green algae [5]. In addition, these low-molecular-weight AAs can only be removed by the chlorination process in traditional water treatment plants [3]. However, chlorination or chloroamination converts the free AAs to a variety of disinfection by-products (DBPs), including trihalomethanes, haloacetaldehydes, haloacetonitriles, haloacetamides and halonitromethanes [6-8]. For example, aspartic acid and Trp can be converted to dichloroacetonitrile [9], while L-tyrosine and aspartic acid form dichloroacetamide [8].

Several methods, such as improved coagulation, nanofiltration, reverse osmosis, ultraviolet (UV) irradiation and advanced oxidation processes, have been proposed to control the number of DBP precursors [10-12]. Of these, low-pressure UV irradiation is a promising alternative for disinfection in drinking water treatment plants because it is a costeffective process with an easily implementable system [13]. Recently, UV disinfection has received considerable attention in the field of water treatment [14]. Thus, UV irradiation 
could potentially be applied to degrade AAs; however, the mechanism and different degradation products have not yet been elucidated.

In this study, the degradation of Trp by UV irradiation was examined in water. Trp, contains an indole ring $[15,16]$ and is a typical naturally occurring AA present in water bodies. The chlorination of Trp produces significant amounts of THMs (trihalomethanes) and dichloroacetonitrile $[17,18]$, which may adversely affect human health.

In this study, the effects of initial Trp concentration, $\mathrm{pH}$, temperature, $\mathrm{NO}_{3}{ }^{-}, \mathrm{HCO}_{3}{ }^{-}$ and $\mathrm{Cl}^{-}$concentrations on Trp removal were investigated. Moreover, the proposed degradation pathway was elucidated.

\section{Materials and Methods}

\subsection{Chemicals}

All chemicals were of analytical grade, except as noted. $\operatorname{Trp}(\geq 98 \%)$ and methanol were obtained from Aladdin (Shanghai, China). Atrazine and t-butanol were purchased from Sigma Aldrich. Sodium dihydrogen phosphate and disodium phosphate were purchased from Sinopharm Chemical Reagent Co. Ltd. (Shanghai, China), and were used as received. All solutions were prepared using ultrapure water (NW Ultrapure water system, HealForce, Shanghai, China), which was obtained from a Milli-Q system with a resistivity $>18 \mathrm{MV} \cdot \mathrm{cm}$.

\subsection{UV Reactor}

UV irradiation experiments were conducted in a UV reactor equipped with a $6 \mathrm{~W}$ LP Hg UV lamp (254 nm, 4P-SE, Philips), as shown in Figure S1. A small stirring rotor was placed at the bottom of the reactor to ensure that all molecules in the solution were homogenously exposed to UV light. Atrazine and hydrogen peroxide were used as actinometers to determine the UV fluence rate $\left(\mathrm{I}_{0} ; 4 \times 10^{-7}\right.$ Einstein s$\left.{ }^{-1} \mathrm{~L}^{-1}\right)$ and effective path length $(\mathrm{b} ; 4.1 \mathrm{~cm})[19,20]$.

\subsection{Experimental Procedure}

All UV-induced Trp degradation experiments were performed at a constant $\mathrm{pH}$, which was maintained using $10 \mathrm{mM}$ phosphate buffers.

To investigate the effects of initial concentrations, temperatures and ionic concentrations on Trp degradation, a $700 \mathrm{~mL}$ testing solution was prepared, which consisted of Trp $(0.6-10 \mathrm{mg} / \mathrm{L})$, nitrate $(0-500 \mathrm{mg} / \mathrm{L})$ and bicarbonate ions $(0-500 \mathrm{mg} / \mathrm{L})$. The effects of $\mathrm{pH}$ and temperature were studied in the ranges of $6-7.5$ and $7-27^{\circ} \mathrm{C}$, respectively. The mixture was stirred using a magnetic stirrer. A constant temperature was maintained by circulating cold water. Samples $(1 \mathrm{~mL})$ were collected at different retention times and t-butanol was added to quench the reaction. These samples were analyzed by liquid chromatography (LC). Samples (500 mL) collected after 0, 10, 20, 40, 60, 90 and 120 min were analyzed by liquid chromatography tandem mass spectrometry (LC-MS-MS).

\subsection{Analytical Methods}

Trp concentration was measured by high-performance liquid chromatography (HPLC; Agilent, Santa, SA). The HPLC system was equipped with an extended C18 column $(4.6 \times 250 \mathrm{~mm}, 5 \mathrm{~mm}$, Waters Co., Milford, USA). Phosphoric acid in methanol (85\% v/v) was used as the mobile phase with a flow rate of $1.0 \mathrm{~mL} / \mathrm{min}$. The excitation wavelength and emission wavelength of Trp were $260 \mathrm{~nm}$ and $340 \mathrm{~nm}$, respectively. The HPLC graphs of Trp can be seen in Figure S2.

-OH was tested with a Bruker A300 EPR Spectrometer manufactured by Bruker, Germany. DMPO was used as an electron spin capture agent. In this experiment, because the phosphoric acid buffer solution could reduce the signal strength of DMPO--OH, no phosphoric acid buffer solution was added to the reaction solution. The process was as follows: $10 \mathrm{mg} / \mathrm{L}$ Trp solution was exposed to UV, then $1 \mathrm{~mL}$ of Trp solution was quickly mixed with $1 \mathrm{~mL}$ of $16000 \mathrm{mg} / \mathrm{L}$ DMPO and transferred into a $200 \mu \mathrm{L}$ capillary tube for 
an EPR test. Computer spectral simulations were carried out by means of Bruker WinEPR Acquisition software.

The intermediate products were characterized by LC-MS-MS. The compounds were separated on a ZORBAX-SB C18 $(250 \mathrm{~mm} \times 4.6 \mathrm{~mm}, 5.0 \mu \mathrm{m})$ column. The mobile phase was acetonitrile-isopropanol (1:1) elution, the flow rate was $1.0 \mathrm{~mL} / \mathrm{min}$, the detection wavelength was $210 \mathrm{~nm}$, the column temperature was $30^{\circ} \mathrm{C}$ and the injection quantity was $10 \mu \mathrm{L}$. Electrospray ion source positive ion mode was adopted and the scanning range was $m / z 100-1500$.

\section{Results}

3.1. Kinetic Model of UV Degradation of Trp

The pseudo first-order reaction kinetic equation is shown in Equation (1):

$$
\mathrm{y}=\mathrm{e}^{-\mathrm{k}_{\mathrm{obs}} \mathrm{t}}
$$

where $\mathrm{t}$ is the reaction time, $\mathrm{y}$ is the ratio of concentration of $\operatorname{Trp}$ at $\mathrm{t}$ to the initial concentration and $\mathrm{k}_{\mathrm{obs}}$ is the reaction rate constant.

The degradation curve of Trp is fitted by Equation (1) and the fitting curve is shown in Figure 1. The linear regression coefficient $R^{2}$ of the curve was greater than 0.98 for Trp, which indicated that its reaction by UV fitted a new pseudo first-order reaction kinetic model.

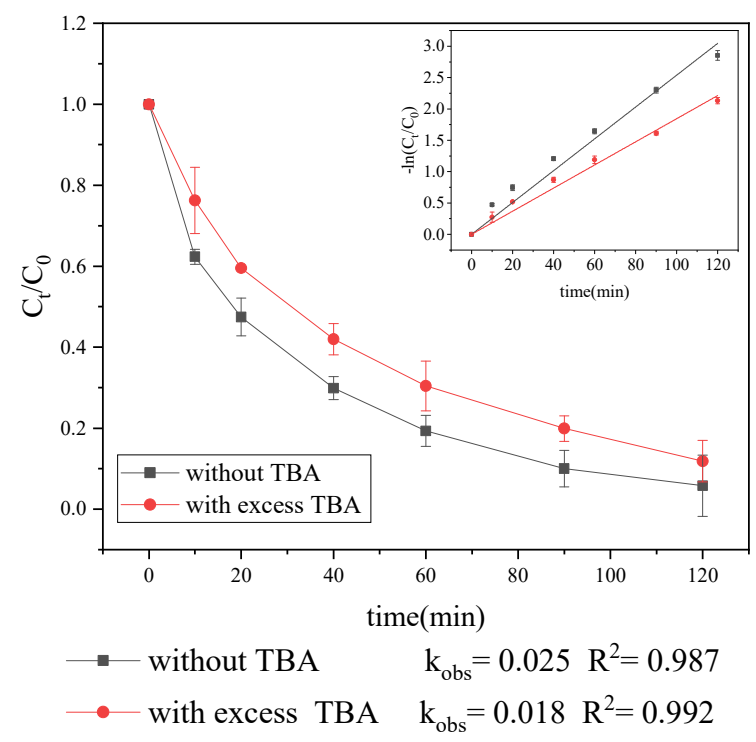

Figure 1. Kinetic model of UV degradation of Trp.

UV degradation principles can be divided into direct degradation and indirect degradation. Direct degradation refers to the direct oxidation, bond breaking, isomerization and rearrangement of organic matter by UV [21]. Indirect degradation refers to the production of radicals such as $\cdot \mathrm{OH}$. In order to verify the existence of $\cdot \mathrm{OH}$, a radical quencher TBA (tert-butyl alcohol, $0.5 \mathrm{mM}$ ) was added during the UV treatment to compare the differences between direct and total degradation with and without TBA. Figure 1 shows that the UV degradation could generate $\cdot \mathrm{OH}$. From two $\mathrm{k}_{\mathrm{obs}}$ of curves, we inferred that degradation of Trp occurred mainly by direct UV degradation.

The first pathway to produce $\cdot \mathrm{OH}$ by UV irradiation is to excite and react Trp with water molecules to generate $\cdot \mathrm{OH}$ [22]. The second pathway is the intermediate reaction of Trp through hydration electrons, superoxide anion radicals and hydrogen peroxide, which finally produces hydroxyl radicals $[23,24]$. The reaction equation is shown in Equations (2) and (3). 
Pathway 1:

$$
\begin{gathered}
\operatorname{Trp}+\mathrm{hv} \rightarrow \operatorname{Trp}^{*} \\
\operatorname{Trp}^{*}+\mathrm{H}_{2} \mathrm{O} \rightarrow \operatorname{Trp}-\mathrm{H}^{*}+\cdot \mathrm{OH}
\end{gathered}
$$

Pathway 2:

$$
\begin{gathered}
\operatorname{Trp}^{*} \rightarrow \operatorname{Trp}^{+}+\mathrm{e}^{-}{ }_{\text {aq }} \\
\mathrm{e}^{-} \text {aq }+\mathrm{O}_{2} \rightarrow \cdot \mathrm{O}_{2}{ }^{-} \\
2 \cdot \mathrm{O}_{2}{ }^{-}+2 \mathrm{H}^{+} \rightarrow \mathrm{H}_{2} \mathrm{O}_{2}+\mathrm{O}_{2} \\
\mathrm{H}_{2} \mathrm{O}_{2}+\mathrm{hv} \rightarrow 2 \cdot \mathrm{OH}
\end{gathered}
$$

\subsubsection{Effect of Initial Trp Concentration}

The degradation of Trp was examined at different initial concentrations (i.e., 0.6, 2, 4 , $6,8 \mathrm{mg} / \mathrm{L}$ ). As displayed in Figure 2, increasing the initial Trp concentration decreased the Trp removal rate, and these findings are consistent with those of previous studies [25,26].

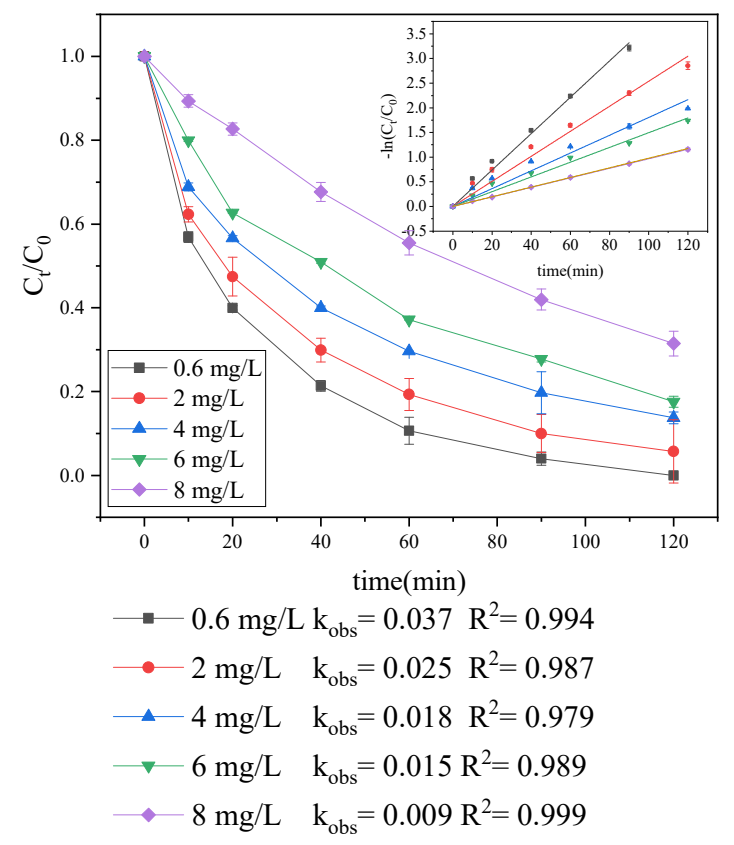

Figure 2. Effect of initial Trp concentration on Trp degradation.

On the one hand, the light quantum generated by unit time UV irradiation effectively remains unchanged. The higher the Trp concentration, the less light quantum captured by a single Trp molecule, which leads to the chemical bond of Trp being less likely to be broken and slows down the direct degradation rate of Trp. On the other hand, the rate of . $\mathrm{OH}$ generation remains constant if the UV intensity is maintained, while the rate of $\cdot \mathrm{OH}$ consumption increases with an increase in the initial Trp concentration [27,28]. Moreover, an increase in the initial Trp concentration increases the amount of organic matter per unit volume, which decreases the exposure of a molecule to UV irradiation. Thus, the concentration of $\cdot \mathrm{OH}$ also decreases, causing the reaction rate to decrease.

In order to analyze the relationship between initial Trp concentration and $\mathrm{k}_{\mathrm{obs}}$, the experimental data were fit to Equation (4), as shown in Figure 3. It was shown that, with the increase in initial $\operatorname{Trp}$ concentration, the $\mathrm{k}_{\mathrm{obs}}$ became smaller and the rate of descent slowed down.

$$
\mathrm{k}_{\mathrm{obs}}=-0.01 \ln \left(\mathrm{C}_{0}\right)+0.03
$$




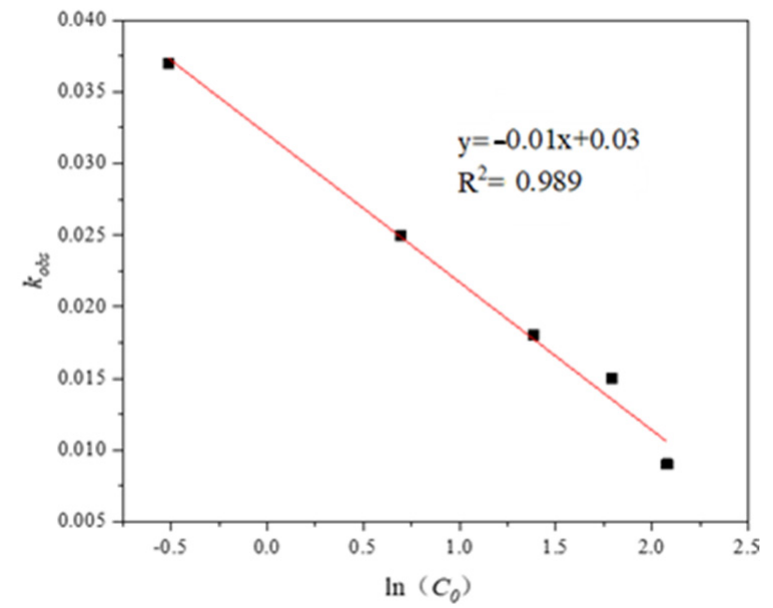

Figure 3. Linear relationship of $\mathrm{C}_{0}$ with $\mathrm{k}_{\mathrm{obs}}$.

\subsubsection{Effect of $\mathrm{pH}$}

It is known that $\mathrm{pH}$ can affect the mechanism and pathways of degradation [21].To clarify how $\mathrm{pH}$ affected the degradation of Trp during UV irradiation, the samples with different $\mathrm{pH}$ (i.e., 6.0, 6.5, 7, 7.5, 8) were prepared; the results are shown in Figure 4. The degradation rate increased with an increase in $\mathrm{pH}$, and was the highest at $\mathrm{pH} 8$, implying that increasing the solution $\mathrm{pH}$ promoted Trp removal.

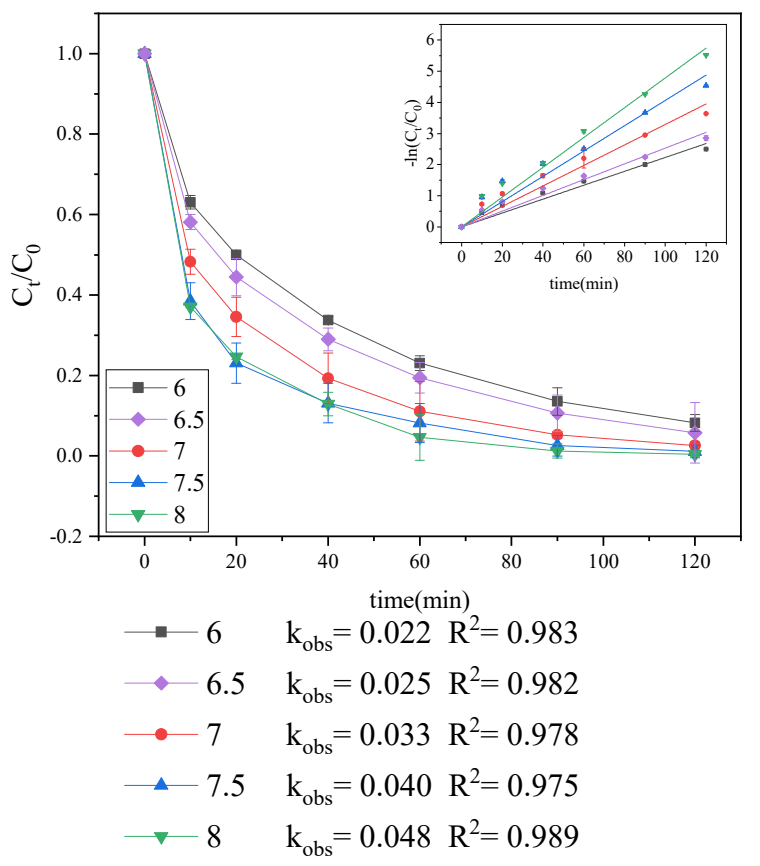

Figure 4. Effect of $\mathrm{pH}$ on Trp degradation.

According to a widely acknowledged previous study, increasing the solution $\mathrm{pH}$ reduces the ratio of $\cdot \mathrm{OH}$, as shown in Equation (5). When the $\mathrm{pH}$ was increased from 4.7 to 8.4, the $\cdot \mathrm{OH}$ concentration decreased by $80 \%$ [29]. However, this experiment found that, with the increase in $\mathrm{pH}$, the degradation rate of Trp increased, which indicates that the main mechanism of Trp degradation is not indirect degradation through the generation of $\cdot \mathrm{OH}$, but direct $\mathrm{UV}$ degradation. Bergman [30] found that the hydrogen bonded to the first carbon in a nitrogen-containing heterocyclic ring is highly acidic, implying that the 
synergistic effect of alkaline conditions and ultraviolet light could promote the ring-opening of nitrogen-containing heterocycles, thus accelerating direct degradation.

$$
\mathrm{OH}^{-}+\cdot \mathrm{OH} \rightarrow \cdot \mathrm{O}+\mathrm{H}_{2} \mathrm{O}
$$

\subsubsection{Effect of Temperature}

The effect of temperature on the degradation of Trp is shown in Figure 5, which demonstrates that Trp degradation is facilitated at a higher temperature. Owing to the low activation energy, the rate constant for the reaction between $\cdot \mathrm{OH}$ and Trp is largely unaffected by reaction temperature [31,32], suggesting that reaction temperature directly contributes to Trp degradation.

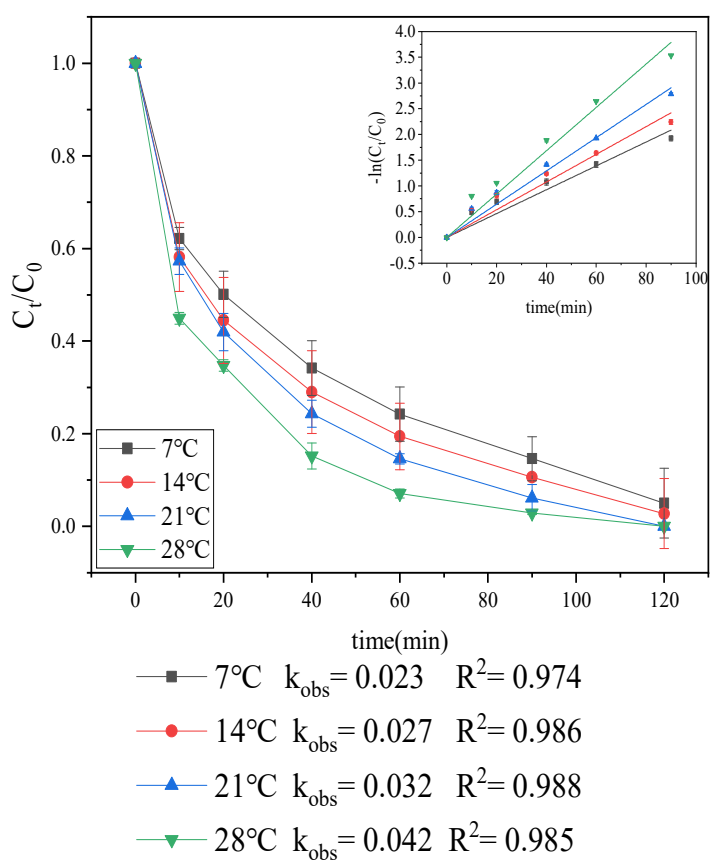

Figure 5. Effect of temperature on Trp degradation.

To further investigate the influence of reaction temperature on Trp degradation, the calculated rate constant $k_{\text {obs, }}$ was fitted with the Arrhenius equation [31], as shown in Equation (6):

$$
\ln \mathrm{k}_{\mathrm{obs}}=\ln \mathrm{A}-\frac{\mathrm{Ea}}{\mathrm{RT}}
$$

where $\mathrm{A}$ is the pre-exponential factor, Ea is the apparent activation energy, $\mathrm{R}$ is the universal gas constant $(8.314 \mathrm{~J} / \mathrm{mol} / \mathrm{K})$ and $\mathrm{T}$ is the temperature in Kelvin.

As shown in Figure 6, Ea was calculated to be approximately $19.65 \mathrm{~kJ} / \mathrm{mol}$. Generally, most activation energy of the chemical reaction ranged from 50 to $250 \mathrm{~kJ} / \mathrm{mol}$, and the lower the activation energy, the easier it is for the reaction to take place. Therefore, temperature has a significant effect on the UV degradation of Trp and it is speculated that temperature promotes the direct degradation of Trp. 


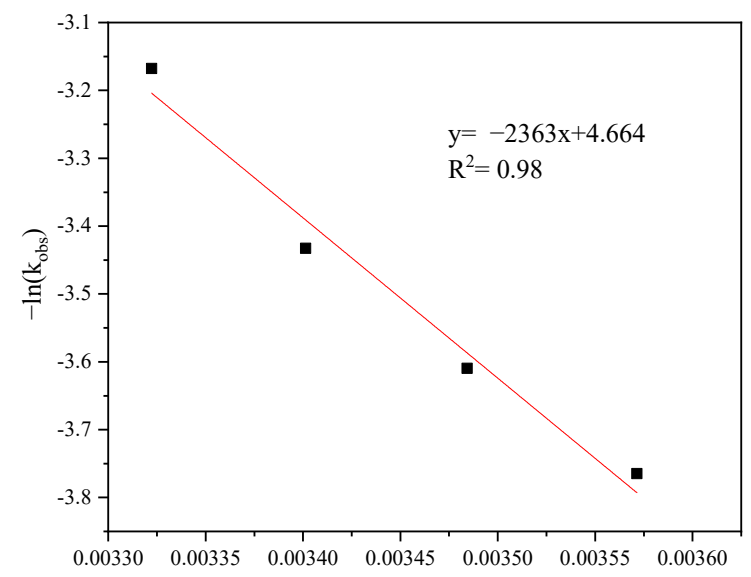

Figure 6. Evaluation of apparent activation energy.

\subsubsection{Effect of Water Matrix}

$\mathrm{HCO}_{3}{ }^{-}$is a common anion (50-200 mg/L) in natural water [33] that can affect the removal rate of organic pollutants [34]. $\mathrm{HCO}_{3}{ }^{-}$can react with $\cdot \mathrm{OH}$ to form $\mathrm{CO}_{3}{ }^{2-}$ and $\mathrm{H}_{2} \mathrm{O}$ (Equation (7)). It should be noted that $\mathrm{pH}$ can significantly affect the form of bicarbonate ions, and when the $\mathrm{pH}$ is too low, hydrolyzed bicarbonate change to carbon dioxide. In order to better study the effect of bicarbonate on the UV degradation of Trp, $\mathrm{pH}$ was set at 7; the result is presented in Figure 7.

$$
\cdot \mathrm{OH}+\mathrm{HCO}_{3}{ }^{-} \rightarrow \mathrm{CO}_{3}{ }^{2-}+\mathrm{H}_{2} \mathrm{O}
$$

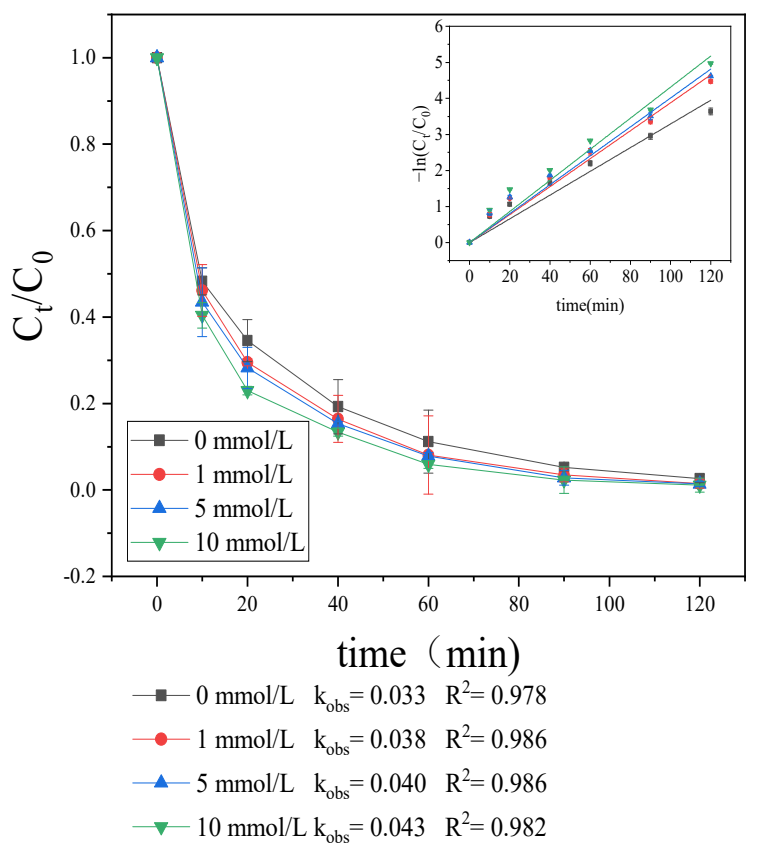

Figure 7. Effect of $\mathrm{HCO}_{3}{ }^{-}$concentration on Trp degradation.

As shown in Figure $7, \mathrm{HCO}_{3}{ }^{-}$can promote the degradation of Trp. Unlike $\cdot \mathrm{OH}$, $\mathrm{HCO}_{3}{ }^{-}$has a high selectivity and preferentially reacts with compounds with electron-rich moieties, such as AAs, via an electron transfer or hydrogen abstraction reaction $[35,36]$. In addition to the functional groups of AAs themselves, Trp has electron-rich indole side chains, which are more likely to react with $\mathrm{HCO}_{3}{ }^{-}$to accelerate the degradation of Trp.

Similar to $\mathrm{HCO}_{3}{ }^{-}, \mathrm{NO}_{3}{ }^{-}$is also widely present in natural water bodies at concentrations ranging from $0.01 \mathrm{mmol} / \mathrm{L}$ to $1 \mathrm{mmol} / \mathrm{L}$. The photolysis of $\mathrm{NO}_{3}{ }^{-}$could generate $\cdot \mathrm{OH}$ 
(Equation (8)), which could degrade the organic matter present in natural water bodies [37]. Figure 8 demonstrates that $\mathrm{NO}_{3}{ }^{-}$accelerates the photodegradation of Trp

$$
\begin{gathered}
\mathrm{NO}_{3}{ }^{-}+\mathrm{hv} \rightarrow \mathrm{NO}_{3}{ }^{-}+\mathrm{NO}_{2}{ }^{-}+\mathrm{O}^{-} \\
\mathrm{NO}_{3}{ }^{-}+\mathrm{hv} \rightarrow \cdot \mathrm{NO}_{2}{ }^{-}+0.5 \mathrm{O}_{2} \\
\mathrm{NO}_{2}{ }^{-}+\mathrm{hv} \rightarrow \cdot \mathrm{ON}+\mathrm{O}^{-} \\
\mathrm{O}^{-}+\mathrm{H}_{2} \mathrm{O} \rightarrow \cdot \mathrm{OH}+\mathrm{OH}^{-}
\end{gathered}
$$

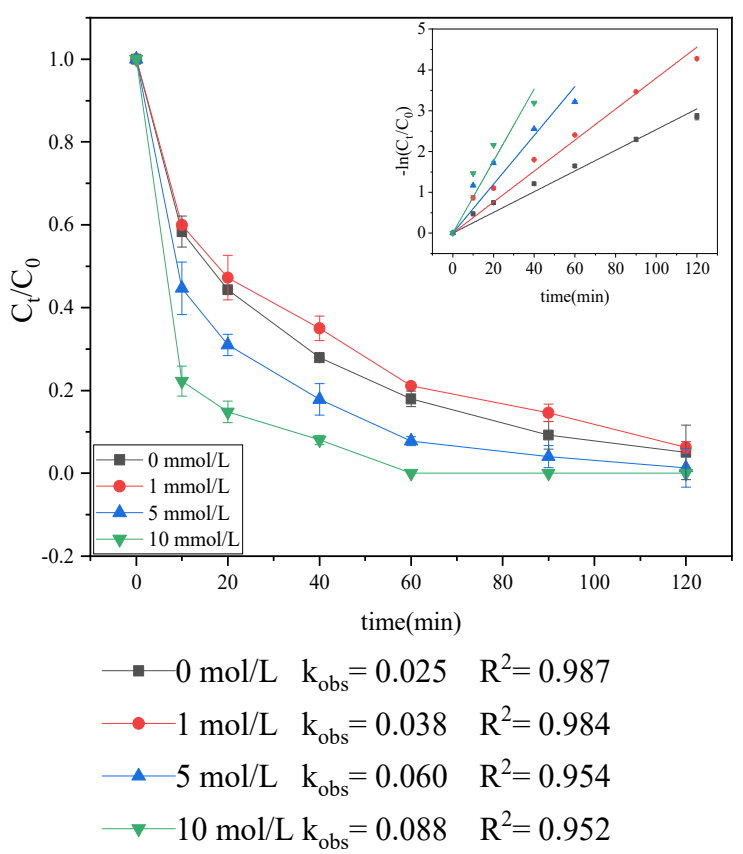

Figure 8. Effect of $\mathrm{NO}_{3}{ }^{-}$concentration on Trp degradation.

Because the concentration of $\mathrm{Cl}^{-}$in natural water is typically $1-100 \mathrm{mg} / \mathrm{L}$, the effect of different concentrations of $\mathrm{Cl}^{-}$on the UV degradation of Trp was also investigated. The experimental results are shown in Figure 9.

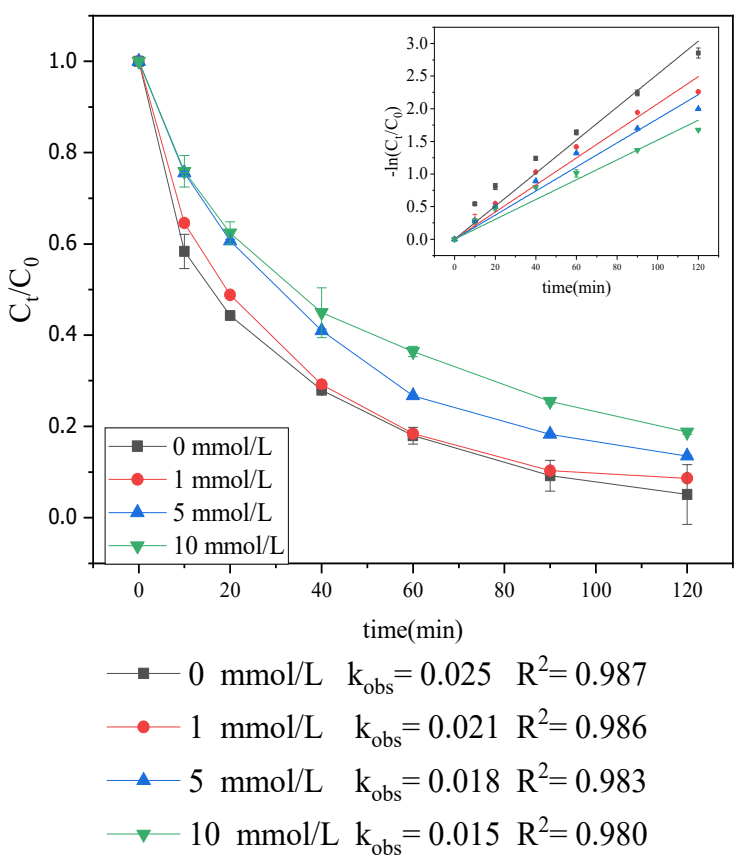

Figure 9. Effect of different concentrations of $\mathrm{Cl}^{-}$on $\operatorname{Trp}$ degradation. 
With the increase in $\mathrm{Cl}^{-}$concentration from $1 \mathrm{mmol} / \mathrm{L}$ to $10 \mathrm{mmol} / \mathrm{L}$, the $\mathrm{k}_{\text {obs }}$ of $\operatorname{Trp}$ decreased from 0.021 to $0.015 \mathrm{~min}^{-1}$, as shown in Figure 9. Chlorine-containing free radical species are known as active chlorine species (RCS), including $\cdot \mathrm{Cl}_{1} \mathrm{HOCl}^{-}$and $\mathrm{Cl}_{2}{ }^{-}$with oxidation potentials of $2.47 \mathrm{~V}, 1.6-1.8 \mathrm{~V}$ and $2.0 \mathrm{~V}$ [38,39], respectively. These radicals have a lower potential than that of $\cdot \mathrm{OH}(\mathrm{E}=2.8 \mathrm{~V})$ [40]. The method of generating RCS can be seen in Equation (9). A number of studies have shown that RCS has a weak ability to oxidize electron-rich organics [38,41,42]; thus, it is speculated that $\cdot \mathrm{OH}$ is converted into active chlorine species with a weaker oxidization ability by the increase in $\mathrm{Cl}^{-}$concentration, which slows down the degradation rate of Trp.

$$
\begin{aligned}
2 \mathrm{Cl}^{-}+\cdot \mathrm{OH}+\mathrm{H}^{+} \leftrightarrow \mathrm{Cl}_{2}^{-}+\mathrm{H}_{2} \mathrm{O} \\
\mathrm{Cl}^{-}+\cdot \mathrm{OH} \leftrightarrow \mathrm{HOCl}^{-} \\
\mathrm{Cl}^{-}+\mathrm{Cl}^{-} \leftrightarrow \mathrm{Cl}_{2}^{-}
\end{aligned}
$$

\subsection{Mechanism of Trp Degradation}

\subsubsection{Generation of Radical Species}

The presence of $\cdot \mathrm{OH}$ in the reaction mixture was further investigated by the addition of a spin trapping agent, 5,5-dimethyl-1-pyrroline-1-oxide (DMPO), followed by electron paramagnetic resonance (EPR) spectroscopy [43]. During this experiment, the phosphate buffer solution was not added in the reaction mixture because it could decrease the amount of DMPO and the signal intensity of the DMPO-OH adduct [44]. The results from the EPR analysis(Figure 10) further verified the formation of $\cdot \mathrm{OH}$.

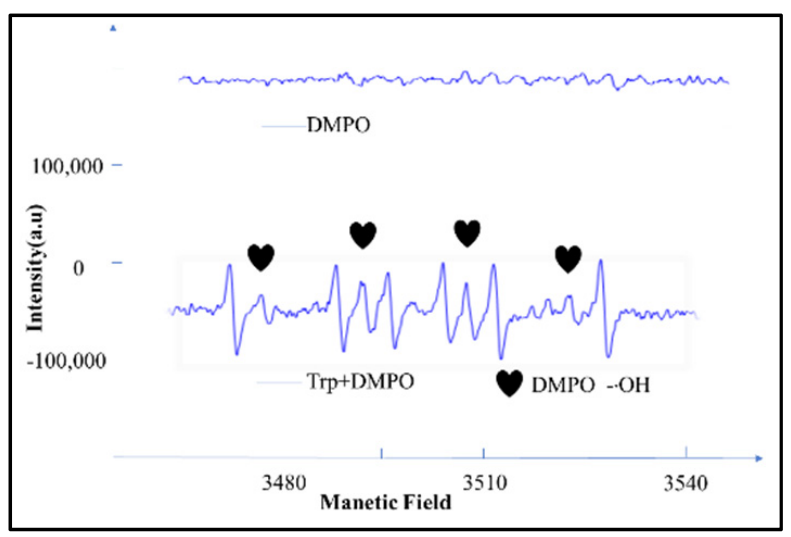

Figure 10. EPR spectra of DMPO and Trp/DMPO samples.

\subsubsection{Degradation Products}

Trp degradation was examined using LC-MS-MS. The secondary mass spectrometry of intermediates is presented in Figures S3-S5, and the atom potential map of Trp is shown in Figure S6. The $\mathrm{N}(0.38)$ on the indole group has a significant difference in atom potential between adjacent Cs (-0.07 and -0.04$)$; thus, it is easier for the heterocyclic structure of Trp to initiate a ring-opening reaction. Moreover, carboxyl can be cleaved easily because of the large potential difference in its $\mathrm{C}-\mathrm{C}$ bond. Based on these intermediates and atom potential map, the proposed degradation pathway of Trp by UV treatment is established and shown in Figure 11. 


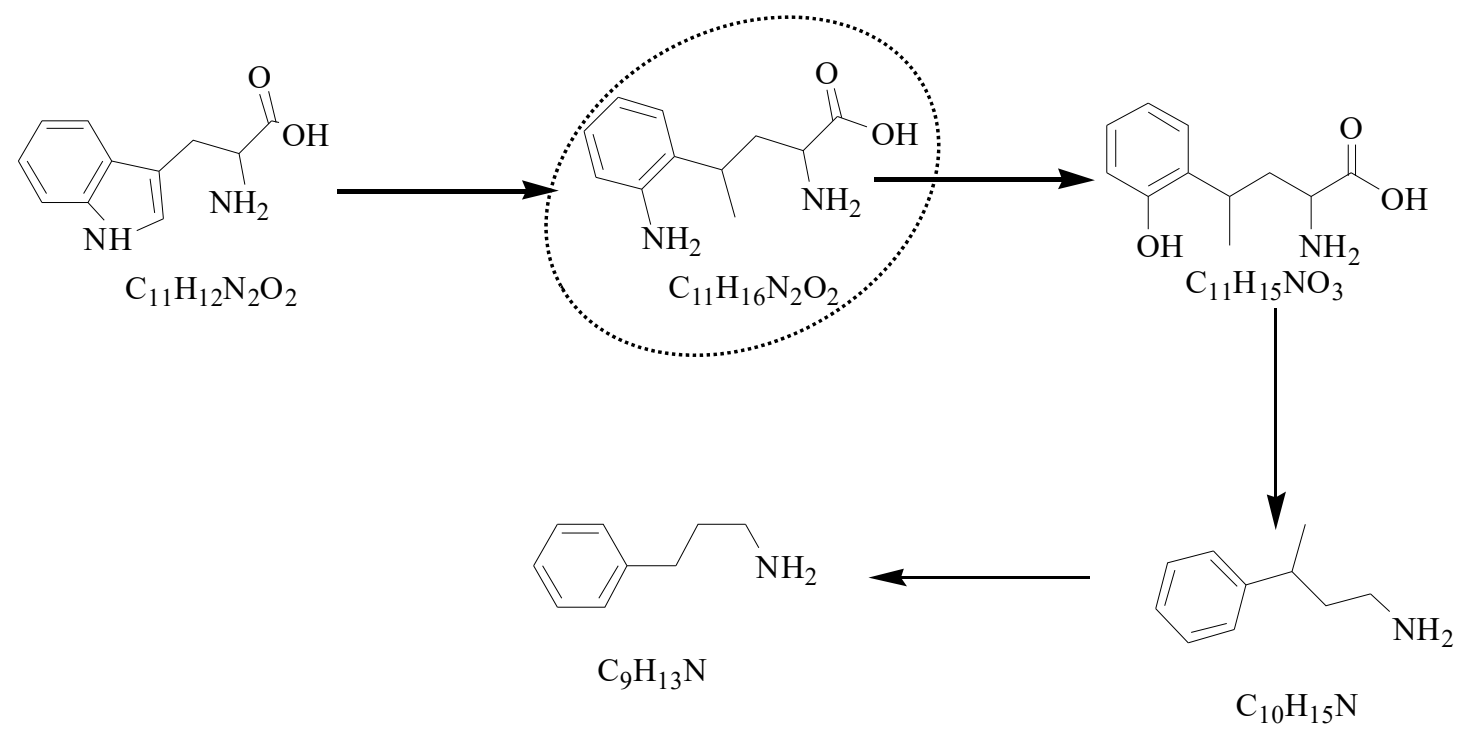

Figure 11. Proposed degradation pathway of Trp by UV treatment.

During the mechanism, Trp was initially converted to $\mathrm{C}_{11} \mathrm{H}_{16} \mathrm{~N}_{2} \mathrm{O}_{2}$ via the cleavage of $\mathrm{C}-\mathrm{N}$ bonds. The aromatic ring in $\mathrm{C}_{11} \mathrm{H}_{16} \mathrm{~N}_{2} \mathrm{O}_{2}$ was attacked by $\cdot \mathrm{OH}$ to afford $\mathrm{C}_{11} \mathrm{H}_{15} \mathrm{NO}_{3}$, after which $\mathrm{C}_{11} \mathrm{H}_{15} \mathrm{NO}_{3}$ was further oxidized to form $\mathrm{C}_{10} \mathrm{H}_{15} \mathrm{~N}$ through de-hydroxy and de-carboxylic reactions. Finally, $\mathrm{C}_{9} \mathrm{H}_{13} \mathrm{~N}$ was formed in the cleavage loss of methyl.

\section{Conclusions}

The degradation curve of Trp fit a pseudo first-order reaction kinetic model, primarily by direct degradation. Degradation was promoted by an increase in $\mathrm{pH}$, temperature, and $\mathrm{HCO}_{3}{ }^{-}$and $\mathrm{NO}_{3}{ }^{-}$concentrations. In contrast, increasing the initial Trp and $\mathrm{Cl}^{-}$concentrations decreased the degradation rate. The Ea value was estimated to be $19.65 \mathrm{~kJ} / \mathrm{mol}$. The EPR results further verified the presence of $\cdot \mathrm{OH}$ in the reaction mixture. The degradation pathway was proposed on the basis of three intermediate products.

Supplementary Materials: The following are available online at https:/ / www.mdpi.com/article/ 10.3390/w13172368/s1, Figure S1: Experimental reactor, Figure S2: HPLC graphs of Trp, Figure S3: Secondary mass spectrometry of $\mathrm{C}_{11} \mathrm{H}_{15} \mathrm{NO}_{3}$, Figure $\mathrm{S} 4$ : Secondary mass spectrometry of $\mathrm{C}_{10} \mathrm{H}_{15} \mathrm{~N}$, Figure S5: Secondary mass spectrometry of $\mathrm{C}_{9} \mathrm{H}_{13} \mathrm{~N}$, Figure S6: The atom potential map of Trp.

Author Contributions: Conceptualization, W.F. and Y.Y.; data curation, W.F. and K.Z.; methodology, Y.Y.; supervision, J.J. All authors have read and agreed to the published version of the manuscript.

Funding: This work was supported by the Major Science and Technology Program for Water Pollution and Treatment (2017ZX07201004).

Institutional Review Board Statement: Not applicable.

Informed Consent Statement: Not applicable.

Conflicts of Interest: The authors declare no conflict of interest.

\section{References}

1. Trehy, M.L.; Yost, R.A.; Miles, C.J. Chlorination byproducts of amino acids in natural waters. Environ. Sci. Technol. 1986, 20, 1117-1122. [CrossRef]

2. Cai, L.; Li, L.; Yu, S.; Guo, J.; Kuppers, S.; Dong, L. Formation of odorous by-products during chlorination of major amino acids in East Taihu Lake: Impacts of UV, UV/PS and UV/ $\mathrm{H}_{2} \mathrm{O}_{2}$ pre-treatments. Water Res. 2019, 162, 427-436. [CrossRef]

3. Dotson, A.; Westerhoff, P. Occurrence and removal of amino acids during drinking water treatment. J. Am. Water Work. Assoc. 2009, 101, 101-115. [CrossRef]

4. Du, P.; Zhao, H.; Cao, H.; Huang, C.H.; Liu, W.; Li, Y. Transformation of halobenzoquinones with the presence of amino acids in water: Products, pathways and toxicity. Water Res. 2017, 122, 299-307. [CrossRef] [PubMed] 
5. How, Z.T.; Linge, K.L.; Busetti, F.; Joll, C.A. Formation of odorous and hazardous by-products from the chlorination of amino acids. Water Res. 2018, 146, 10-18. [CrossRef]

6. Bond, T.; Templeton, M.R.; Graham, N. Precursors of nitrogenous disinfection by-products in drinking water-a critical review and analysis. J. Hazard. Mater. 2012, 235, 1-16. [CrossRef]

7. Shah, A.D.; Mitch, W.A. Halonitroalkanes, halonitriles, haloamides, and N-nitrosamines: A critical review of nitrogenous disinfection byproduct formation pathways. Environ. Sci. Technol. 2012, 46, 119-131. [CrossRef] [PubMed]

8. Chu, W.; Yao, D.; Deng, Y.; Sui, M.; Gao, N. Production of trihalomethanes, haloacetaldehydes and haloacetonitriles during chlorination of microcystin-Lr and impacts of pre-oxidation on their formation. J. Hazard. Mater. 2017, 327, 153-160. [CrossRef] [PubMed]

9. Bond, T.; Henriet, O.; Goslan, E.H.; Parsons, S.A.; Jefferson, B. Disinfection byproduct formation and fractionation behavior of natural organic matter surrogates. Environ. Sci. Technol. 2009, 43, 5982-5989. [CrossRef]

10. Zhang, J.; Liu, J.; He, C.S.; Qian, C.; Mu, Y. Formation of iodo-trihalomethanes (I-THMs) during disinfection with chlorine or chloramine: Impact of $\mathrm{UV} / \mathrm{H}_{2} \mathrm{O}_{2}$ pre-oxidation. Sci. Total Environ. 2018, 640, 764-771. [CrossRef]

11. Sarathy, S.R.; Mohseni, M. The impact of $\mathrm{UV} / \mathrm{H}_{2} \mathrm{O}_{2}$ advanced oxidation on molecular size distribution of chromophoric natural organic matter. Environ. Sci. Technol. 2007, 41, 8315-8320. [CrossRef] [PubMed]

12. Qi, W.; Zhang, H.; Hu, C.; Liu, H.; Qu, J. Effect of ozonation on the characteristics of effluent organic matter fractions and subsequent associations with disinfection by-products formation. Sci. Total Environ. 2018, 610, 1057-1064. [CrossRef]

13. Choi, Y.; Choi, Y.J. The effects of UV disinfection on drinking water quality in distribution systems. Water Res. 2010, 44, 115-122. [CrossRef]

14. Wang, A.Q.; Xu, B.; Zhang, T.-Y.; Chen, Y.-Y.; Gao, N.-Y. Effect of UV irradiation and UV/chlorine processes on trichloronitromethane formation during chlorination of ronidazole. CLEAN-Soil Air Water 2017, 45, 160-163. [CrossRef]

15. Szajdak, L.; Osterberg, R. Amino acids present in humic acids from soils under different cultivations. Environ. Int. 1996, 22, 331-334. [CrossRef]

16. Li, C.; Lin, Q.; Dong, F.; Li, Y.; Luo, F.; Zhang, K. Formation of iodinated trihalomethanes during chlorination of amino acid in waters. Chemosphere 2019, 217, 355-363. [CrossRef]

17. Kaczynski, S.E.; Kieber, R.J. Hydrophobic C18 bound organic complexes of chromium and their potential impact on the geochemistry of $\mathrm{Cr}$ in natural-waters. Environ. Sci. Technol. 1994, 28, 799-804. [CrossRef] [PubMed]

18. Wang, X.; Wang, J.; Zhang, Y.; Shi, Q.; Zhang, H.; Zhang, Y.; Yang, M. Characterization of unknown iodinated disinfection byproducts during chlorination/chloramination using ultrahigh resolution mass spectrometry. Sci. Total Environ. 2016, 554, 83-88 [CrossRef]

19. Beltran, F.J.; Ovejero, G.; Garcia-Araya, J.F.; Rivas, J. Oxidation of polynuclear aromatic hydrocarbons in water. 2. UV radiation and ozonation in the presence of UV radiation. Ind. Eng. Chem. Res. 1995, 34, 1607-1615. [CrossRef]

20. Canonica, S.; Meunier, L.; Von Gunten, U. Phototransformation of selected pharmaceuticals during UV treatment of drinking water. Water Res. 2008, 42, 121-128. [CrossRef] [PubMed]

21. Ji, Y.; Yang, Y.; Zhou, L.; Wang, L.; Lu, J.; Ferronato, C.; Chovelon, J.M. Photodegradation of sulfasalazine and its human metabolites in water by UV and UV/peroxydisulfate processes. Water Res. 2018, 133, 299-309. [CrossRef] [PubMed]

22. Alegria, A.E.; Ferrer, A.; Sepulveda, E. Photochemistry of water-soluble quinones. production of a water-derived spin adduct. Photochem. Photobiol. 1997, 66, 436-442. [CrossRef] [PubMed]

23. Thomas-Smith, T.E.; Blough, N.V. Photoproduction of hydrated electron from constituents of natural waters. Environ. Sci. Technol. 2001, 35, 2721-2726. [CrossRef]

24. Mckay, G.; Rosario-Ortiz, F.L. Temperature dependence of the photochemical formation of hydroxyl radical from dissolved organic matter. Environ. Sci. Technol. 2015, 49, 4147-4154. [CrossRef]

25. Freuze, I.; Brosillon, S.; Arlot, J.; Laplanche, A.; Tozza, D.; Cavard, J. Impact of UV-irradiation on the formation of odorous chloroaldimines in drinking water. Chemosphere 2006, 63, 1660-1666. [CrossRef] [PubMed]

26. Tian, F.X.; Xu, B.; Lin, Y.L.; Hu, C.Y.; Zhang, T.Y.; Gao, N.Y. Photodegradation kinetics of iopamidol by UV irradiation and enhanced formation of iodinated disinfection by-products in sequential oxidation processes. Water Res. 2014, 58, 198-208. [CrossRef] [PubMed]

27. Li, M.; Li, W.; Bolton, J.R.; Blatchley, E.R., III; Qang, Z. Organic pollutant degradation in water by the vacuumultraviolet/ultraviolet $/ \mathrm{H}_{2} \mathrm{O}_{2}$ process: Inhibition and enhancement roles of $\mathrm{H}_{2} \mathrm{O}_{2}$. Environ. Sci. Technol. 2019, 53, 912-918. [CrossRef]

28. Xie, P.; Yue, S.; Ding, J.; Wan, Y.; Li, X.; Ma, J.; Wang, Z. Degradation of organic pollutants by Vacuum-Ultraviolet (VUV): Kinetic model and efficiency. Water Res. 2018, 133, 69-78. [CrossRef] [PubMed]

29. Wu, Z.; Guo, K.; Fang, J.; Yang, X.; Xiao, H.; Hou, S.; Kong, X.; Shang, C.; Yang, X.; Meng, F.; et al. Factors affecting the roles of reactive species in the degradation of micropollutants by the UV/chlorine process. Water Res. 2017, 126, 351-360. [CrossRef]

30. Bergman, J.; Venemalm, L. Efficient synthesis of 2-chloro-, 2-bromo-, and 2-iodoindole. J. Org. Chem. 1992, 57, $2495-2497$. [CrossRef]

31. Xie, P.; Zou, Y.; Jiang, S.; Wang, J.; Zhang, L.; Wang, Z.; Yue, S.; Feng, X. Degradation of imipramine by vacuum ultraviolet (VUV) System: Influencing parameters, mechanisms, and variation of acute toxicity. Chemosphere 2019, 233, 282-291. [CrossRef] 
32. Buxton, G.V.; Greenstock, C.L.; Helman, W.P.; Ross, A.B. Critical review of rate constants for reactions of hydrated electrons, hydrogen atoms and hydroxyl radicals (.Oh/.O-) in aqueous solution. J. Phys. Chem. Ref. Data 1988, 17, 513-886. [CrossRef]

33. Ma, J.; Graham, N.J.D. Degradation of atrazine by manganese-catalysed ozonation-influence of radical scavengers. Water Res. 2000, 34, 3822-3828. [CrossRef]

34. Tan, C.; Gao, N.; Zhou, S.; Xiao, Y.; Zhuang, Z. Kinetic study of acetaminophen degradation by UV-based advanced oxidation processes. Chem. Eng. J. 2014, 253, 229-236. [CrossRef]

35. Lai, W.W.P.; Hsu, M.H.; Lin, A.Y.C. The role of bicarbonate anions in methotrexate degradation via UV/TiO2: Mechanisms, reactivity and increased toxicity. Water Res. 2017, 112, 157-166. [CrossRef] [PubMed]

36. Adams, G.E.; Aldrich, J.E.; Bisby, R.H.; Cundall, R.B.; Redpath, J.L.; Willson, R.L. Selective free radical reactions with proteins and enzymes: Reactions of inorganic radical anions with amino acids. Radiat. Res. 1972, 49, 278-289. [CrossRef]

37. Guo, Z.-B.; Lin, Y.-L.; Xu, B.; Hu, C.Y.; Huang, H.; Zhang, T.-Y.; Chu, W.-H.; Gao, N.-Y. Factors affecting THM, HAN and HNM formation during UV-chlor(am)ination of drinking water. Chem. Eng. J. 2016, 306, 1180-1188. [CrossRef]

38. Gao, Y.Q.; Zhang, J.; Li, C.; Tian, F.X.; Gao, N.Y. Comparative evaluation of metoprolol degradation by UV/chlorine and $\mathrm{UV} / \mathrm{H} 2 \mathrm{O} 2$ processes. Chemosphere 2020, 243, 125325. [CrossRef]

39. Armstrong, D.A.; Huie, R.E.; Koppenol, W.H.; Lymar, S.V.; Merenyi, G.; Neta, P.; Ruscic, B.; Stanbury, D.M.; Steenken, S.; Wardman, P. Standard electrode potentials involving radicals in aqueous solution: Inorganic radicals (IUPAC Technical Report). Pure Appl. Chem. 2015, 87, 1139-1150. [CrossRef]

40. Guan, Y.H.; Ma, J.; Li, X.C.; Fang, J.Y.; Chen, L.W. Influence of pH on the formation of sulfate and hydroxyl radicals in the UV/peroxymonosulfate system. Environ. Sci. Technol. 2011, 45, 9308-9314. [CrossRef]

41. Guo, K.; Wu, Z.; Yan, S.; Yao, B.; Song, W.; Hua, Z.; Zhang, X.; Kong, X.; Li, X.; Fang, J. Comparison of the UV/CHLORINE and $\mathrm{UV} / \mathrm{H} 2 \mathrm{O} 2$ processes in the degradation of PPCPs in simulated drinking water and wastewater: Kinetics, radical mechanism and energy requirements. Water Res. 2018, 147, 184-194. [CrossRef] [PubMed]

42. Guo, Z.B.; Lin, Y.L.; Xu, B.; Huang, H.; Zhang, T.Y.; Tian, F.X.; Gao, N.Y. Degradation of chlortoluron during UV irradiation and $\mathrm{UV} /$ chlorine processes and formation of disinfection by-products in sequential chlorination. Chem. Eng. J. 2016, 283, 412-419. [CrossRef]

43. Watts, R.J.; Teel, A.L. Hydroxyl radical and non-hydroxyl radical pathways for trichloroethylene and perchloroethylene degradation in catalyzed H2O2 propagation systems. Water Res. 2019, 159, 46-54. [CrossRef] [PubMed]

44. Fadda, A.; Barberis, A.; Sanna, D. Influence of $\mathrm{pH}$, buffers and role of quinolinic acid, a novel iron chelating agent, in the determination of hydroxyl radical scavenging activity of plant extracts by Electron Paramagnetic Resonance (EPR). Food Chem. 2018, 240, 174-182. [CrossRef] 